\title{
Gold nanoparticles enhance methylene blue- induced photodynamic therapy: a novel therapeutic approach to inhibit Candida albicans biofilm
}

This article was published in the following Dove Press journal:

International Journal of Nanomedicine

28 June 2012

Number of times this article has been viewed

\author{
Shakir Khan' \\ Fahad Alam² \\ Ameer Azam² \\ Asad U Khan' \\ 'Interdisciplinary Biotechnology Unit, \\ ${ }^{2}$ Center of Excellence in Material \\ Science (Nanomaterials), Aligarh \\ Muslim University, Aligarh, India
}

Correspondence: Asad U Khan Interdisciplinary Biotechnology Unit, Aligarh Muslim University,

Aligarh 202002, India

$\mathrm{Tel}+9 \mid 9837021912$

Fax +9| $57|272| 776$

Email asad.k@rediffmail.com

\begin{abstract}
This article explores the novel gold nanoparticle-enhanced photodynamic therapy of methylene blue against recalcitrant pathogenic Candida albicans biofilm. Physiochemical (X-ray diffraction, ultraviolet-visible absorption, photon cross-correlation, FTIR, and fluorescence spectroscopy) and electron microscopy techniques were used to characterize gold nanoparticles as well as gold nanoparticle-methylene blue conjugate. A $38.2-\mathrm{J} / \mathrm{cm}^{2}$ energy density of 660-nm diode laser was applied for activation of gold nanoparticle-methylene blue conjugate and methylene blue against $C$. albicans biofilm and cells. Antibiofilm assays, confocal laser scanning, and electron microscopy were used to investigate the effects of the conjugate. Physical characteristics of the gold nanoparticles $(21 \pm 2.5 \mathrm{~nm}$ and $0.2 \mathrm{mg} / \mathrm{mL})$ and methylene blue $(20 \mu \mathrm{g} / \mathrm{mL})$ conjugation were confirmed by physicochemical and electron microscopy techniques. Antibiofilm assays and microscopic studies showed significant reduction of biofilm and adverse effect against Candida cells in the presence of conjugate. Fluorescence spectroscopic study confirmed type I photo toxicity against biofilm. Gold nanoparticle conjugate-mediated photodynamic therapy may be used against nosocomially acquired refractory Candida albicans biofilm.
\end{abstract}

Keywords: Candida biofilm, gold nanoparticle-methylene blue conjugate, photodynamic therapy

\section{Introduction}

Biofilms are spatially structured heteromorphic microbial communities ensconced in exopolymeric matrix material. ${ }^{1,2}$ It has been shown that a substantial amount of microbial infections occur through biofilm formation. ${ }^{3}$ Candida albicans is a frequently isolated fungal species from infections and recurrently associated with biofilm formation. ${ }^{4}$ It is generally found as a harmless ubiquitous commensal species in normal microbiota of humans, such as in the gastrointestinal and genitourinary tracts. ${ }^{5}$ However, under conditions of immune dysfunction, colonizing C. albicans possess the capacity to opportunistically cause life-threatening infections in immunocompromised patients. ${ }^{6,7}$ Since last century, Candida biofilm has played an indispensable role in health care-related infections. C. albicans is currently regarded as the fourth- and third-leading cause of hospital-acquired bloodstream and urinary tract infections, respectively. ${ }^{8}$ In the US, candidemia has become recalcitrant and the fourth-leading hospital-acquired infection. ${ }^{9}$

Candida biofilm is one of the main causes of clinical repercussions through encounters with such implanted biomaterials as intravascular catheters, pacemakers, prostheses, stents, shunts, urinary catheters, and orthopedic implants. Hence, these 
implants serve as colonies as well as inseminating reservoirs of further Candida infections. ${ }^{8}$

Biofilm is highly resistant against drug molecules as compared to planktonic cells. ${ }^{10}$ Despite a growing antifungal armamentarium, recalcitrant Candida biofilm presents multiple complex factors against antimicrobial agents, and these multifactorial phenomena need to be further unraveled. Among the most important factors are biofilm matrix or exopolmeric substance (EPS), high density of cells in biofilm, presence of presister cells, and drug-efflux pumps. $^{11-15}$

Ambient matrix or EPS produced by sessile cells of biofilm recently gained the spotlight and imparting the impregnation of drug molecules and putative charge barrier. ${ }^{16,17}$ Recently, photodynamic therapy (PDT) emerged as an alternative to conventional treatment of infections caused by $C$. albicans. ${ }^{18,19}$ In PDT, photosensitizing drugs render the type I and type II phototoxicity in the presence of specific wavelengths of light. ${ }^{20}$ Irradiation of photosensitizers with appropriate wavelengths of light in the presence of molecular oxygen produces highly cytotoxic reactive oxygen species such as hydroxyl free radicals (type I phototoxicity) and singlet oxygen (type II phototoxicity). ${ }^{21}$ Photosensitizer thiazine dyes such as methylene blue (MB), toluidine blue $\mathrm{O}$ (TBO), and pthalocyanine have been shown to be phototoxic against Pseudomonas aeruginosa and Porphyromonas gingivalis biofilm. ${ }^{22-24}$ Recently, it has also been reported that $\mathrm{MB}$ also has fungicidal effects against C. albicans. ${ }^{18,19}$

Colloidal gold nanoparticles (GNPs) have resilient properties compared to other inorganic nanoparticles, such as unique plasmon-resonance optical properties and a bioconjugation surface for molecular probes. These unique properties have drawn attention with a view to developing a totally different method in the field of nanomedicine. ${ }^{25}$ GNP has been used as a carrier of antitumor drugs, antibodies, antibiotics, and other drugs for selective killing of diseased cells and microbes. ${ }^{26-28}$ GNP per se did not have any antimicrobial activity, but when coupled with antibiotics showed significant antimicrobial effect. ${ }^{28,29}$

Cationic thiazine dyes such as TBO and MB showed strong interaction with GNP by increased ultraviolet (UV)visible absorption. ${ }^{30}$ It has been reported that TBO shows enhanced antibacterial properties when coupled with GNP as compared to TBO alone. ${ }^{31}$ Hence we initiated this study to explore novel Candida antibiofilm activity by amalgamating the photocytotoxic properties of MB and antimicrobial enhancer properties of GNP.

\section{Materials and methods}

\section{Synthesis of gold nanoparticles}

GNPs were synthesized in colloidal form by a modified Turkevich-Frens method. ${ }^{32,33}$ First, $1 \mathrm{mM} \mathrm{HAuCl}_{4}$ (Sigma-Aldrich, St Louis, MO) was mixed with $20 \mathrm{~mL}$ distilled water and kept on a hot plate in stirring condition at about $80^{\circ} \mathrm{C}$, then $1 \%$ of trisodium citrate dehydrate $\left(\mathrm{Na}_{3} \mathrm{C}_{6} \mathrm{O}_{7} \cdot 2 \mathrm{H}_{2} \mathrm{O}\right.$; Sigma-Aldrich) reducing agent was added to the solution in stirring condition. Gradually, the color of the solution changed from transparent to red, and after 10 minutes it changed to a deep-red wine color, indicating colloidal GNP formation.

\section{Spectroscopic characterization of synthesized gold nanoparticles}

UV-visible spectra of GNP were taken using a double-beam UV-visible spectrophotometer (PerkinElmer, Boston, MA) with wavelength ranging from 400 to $700 \mathrm{~nm}$ in Milli-Q solvent. The X-ray powder diffraction (XRD) pattern was recorded using a Rigaku (Tokyo, Japan) Miniflex X-ray diffractometer with $\mathrm{Cu} K_{\alpha}$ radiation $(\lambda=1.54060 \AA)$ in $2 \theta$ ranging from $30^{\circ}$ to $80^{\circ}$. GNP hydrodynamic particle size distribution analysis was done by a particle size analyzer (Nanophox; Sympatec, Clausthal-Zellerfeld, Germany) based on photon cross-correlation spectroscopy.

\section{Growth conditions of organism}

C. albicans (ATCC 90028) was grown in yeast peptone dextrose medium $1 \%$ yeast extract, $2 \%$ peptone, $2 \%$ dextrose (HiMedia, Mumbai, India). Batches of medium $(20 \mathrm{~mL}$ in 250-mL Erlenmeyer flasks) were inoculated with freshly grown $C$. albicans in yeast peptone dextrose agar plates and incubated overnight in an orbital shaker (200 rpm) at $30^{\circ} \mathrm{C}$ under aerobic conditions. Cells were harvested and washed twice in sterile phosphate buffer saline (PBS) ( $p H$ 7.4). Cells were resuspended in Roswell Park Memorial Institute (RPMI) 1640 supplemented with L-glutamine and buffered with morpholinepropanesulfonic acid (HiMedia) and adjusted to the desired density after measurement with a hematocytometer.

\section{Determination of minimum inhibitory concentration (MIC) and minimum fungicidal concentration (MFC)}

The photosensitizer, MB, was purchased from Sigma-Aldrich, and stock solution $(1.0 \mathrm{mg} / \mathrm{mL})$ was made in PBS $(10 \mathrm{mM}$ phosphate buffer, $2.7 \mathrm{mM}$ potassium chloride, $137 \mathrm{mM}$ 
sodium chloride; $\mathrm{pH}$ 7.4). A twofold serial dilution of the $\mathrm{MB}$ (initial concentration $1.0 \mathrm{mg} / \mathrm{mL}$ ) was performed. For the GNP-MB conjugate, after twofold serial dilution of $\mathrm{MB}$, a constant concentration of GNP $(0.2 \mathrm{mg} / \mathrm{mL})$ was added to each diluted solution. Each inoculum was prepared in normal saline, and density was adjusted to a $0.5 \mathrm{McF}$ arland standard and diluted to 1:100 for the broth microdilution procedure. After treatment with irradiation at 12 hours, microtiter plates continue to incubate at $37^{\circ} \mathrm{C}$ and MIC was recorded after 24 hours. MFC was determined by subculturing the test dilutions on to a fresh solid medium and incubating for a further 24 hours. The highest dilution that yielded no fungal growth on solid medium was taken as MFC.

\section{Spectroscopic measurements of GNP-MB conjugate}

A double-beam UV-visible spectrophotometer (PerkinElmer) was used to characterize the synthesized GNP and measure the mode of interaction of GNP with MB photosensitizer. Scanning was in the 400-700-nm wavelength range. Fluorescence spectra were recorded on a Hitachi (Tokyo, Japan) F-4500X fluorescence spectrometer controlled by a personal computer data-processing unit. The excitation was done at $600 \mathrm{~nm}$ and the emission spectra from $500 \mathrm{~nm}$ to $800 \mathrm{~nm}$ were collected. All excitation and emission slits were set at $1.5 \mathrm{~nm}$.

FTIR measurement of the MB and GNP-MB conjugate was carried out with a Nicolet Magna 750 FT-IR spectrophotometer (DTGS detector, Ni-chrome source and $\mathrm{KBr}$ beam splitter; Thermo Fisher Scientific, Waltham, MA) with a total of 100 scans and resolution of $16 \mathrm{~cm}^{-1}$ at a range of 400-4000 $\mathrm{cm}^{-1}$, using silver bromide windows at room temperature.

\section{Photosensitization of $M B$ and GNP-MB conjugate}

$\mathrm{MB}$ and GNP-MB conjugate were activated or photosensitized during treatment against Candida biofilm and C. albicans cells. Semiconductor AlGaInP diode laser (ML101J27; Mitsubishi, Tokyo, Japan) with 660-nm wavelength light source and output power of $120 \mathrm{~mW}$ was used for photosensitization. A laser illuminated area of $0.12 \mathrm{~cm}^{2}$ with energy density of $38.2 \mathrm{~J} / \mathrm{cm}^{2}$ was used for 40 seconds for both MB and conjugate activation. In all Candida antibiofilm and antimicrobial assays, MB and GNP-MB conjugate were treated and activated at 6 and 18 hours during 12- and 24-hour incubation periods, respectively.

\section{Candida biofilm formation}

Biofilms were produced on commercially available presterilized, polystyrene, flat-bottom 96-well microtiter plates. At first, $100 \mu \mathrm{L}$ of a standardized C. albicans cell suspension ( $10^{7}$ cells/mL in RPMI 1640) was transferred into each well of a microtiter plate, and the plate was incubated for 1.5 hours at $37^{\circ} \mathrm{C}$ in a shaker at $75 \mathrm{rpm}$ to allow for adherence to the surface of the wells. Three wells of each microtiter plate were used as control in an identical fashion, except that no Candida suspensions were added. Following the adhesion phase, the cell suspensions were aspirated and each well was washed twice with $150 \mu \mathrm{L}$ of PBS to remove loosely adherent cells. A total of $100 \mu \mathrm{L}$ of RPMI 1640 was then transferred into each of the washed wells with a pipette, and the plates were incubated at $37^{\circ} \mathrm{C}$ in a shaker at $75 \mathrm{rpm}$. The biofilm was allowed to develop for 24 hours and used in different assays. All assays were carried out on three different occasions in triplicate.

\section{Crystal violet-staining assay}

Control, GNP, MB and GNP-MB conjugate-treated Candida biofilm were assessed by microdilution method and quantified by crystal violet (HiMedia) assay, as described earlier. ${ }^{34,35}$ Treated and control biofilm-coated wells of microtiter plates were washed twice with $200 \mu \mathrm{L}$ of PBS and then air-dried for 45 minutes. Then, each of the washed wells was stained with $110 \mu \mathrm{L}$ of $0.4 \%$ aqueous crystal violet solution for 45 minutes. Afterwards, each well was washed four times with $350 \mu \mathrm{L}$ of sterile distilled water and immediately destained with $200 \mu \mathrm{L}$ of $95 \%$ ethanol. After 45 minutes of destaining, $100 \mu \mathrm{L}$ of destaining solution was transferred to a new well and the amount of the crystal violet stain in the destaining solution measured with a microtiter plate reader (iMark; Bio-Rad, Hercules, California) at $595 \mathrm{~nm}$. The absorbance for the controls was subtracted from the test values to minimize background interference.

\section{XTT biofilm reduction assay}

This assay was performed as described previously. ${ }^{36} 2,3-$ Bis (2-methoxy-4-nitro-5-sulfophenyl)-5-([phenylamino] carbonyl)-2H-tetrazolium hydroxide (XTT) (Sigma-Aldrich) was dissolved in PBS at a final concentration of $1 \mathrm{mg} / \mathrm{L}$. The solution was filter sterilized using a $0.22-\mathrm{mm}$ pore-size filter and stored at $-70^{\circ} \mathrm{C}$ until required. Menadione (SigmaAldrich) solution $(0.4 \mathrm{mM})$ was also prepared and filtered immediately before each assay. Prior to each assay, XTT solution was thawed and mixed with menadione solution at a volume ratio of 20:1. The adherent cells in treated and 
control Candida biofilm, as previously described in crystal violet assay, were washed four times with $200 \mu \mathrm{L}$ of PBS to remove loosely adherent or planktonic cells. Afterwards, $158 \mu \mathrm{L}$ of PBS, $40 \mu \mathrm{L}$ of XTT, and $2 \mu \mathrm{L}$ of menadione inoculated each of the prewashed wells. After incubation in the dark for 4 hours at $37^{\circ} \mathrm{C}, 100 \mu \mathrm{L}$ of the solution was transferred to a new well and a colorimetric change in the solution measured using a microtiter plate reader (iMark) at $490 \mathrm{~nm}$.

\section{Electron microscopy of GNP, GNP-MB conjugate, Candida biofilm and Candida cells}

Transmission electron microscopy (TEM) was used to determine the actual size, shape, and pattern of arrangement of synthesized GNP and GNP-MB conjugate. TEM was also used to measure the thickness of the MB layer around GNP. Colloidal GNP and GNP-MB conjugate droplets were placed on a copper grid and dried in desiccators before viewing under a field-emission electron microscope (JEM-2100F; Jeol, Tokyo, Japan) at $120 \mathrm{kV}$.

For Candida cells, TEM is the standard method used, as described elsewhere. ${ }^{37}$ Control and treated culture material was removed by centrifugation at $1000 \mathrm{rpm}$ for 10 minutes and the suspended pellet again centrifuged with PBS (pH 7.4). Secondary fixation was done in 1\% osmium tetroxide for 2-3 hours at $4^{\circ} \mathrm{C}$ and washed with PBS (pH 7.4). Samples were then completely dehydrated by serially washing with ethanol and embedded in araldite CY 212 (Taab, Aldermaston, UK) resin for making the cell-pellet blocks. Ultrathin sections of cells were stained with uranyl acetate and lead citrate and observed under the JEM-2100F microscope at $120 \mathrm{kV}$.

The effects of GNP-MB conjugate on the morphogenesis of C. albicans cells in Candida biofilm were observed by scanning electron microscopy (SEM), examination as described elsewhere. ${ }^{38}$ For SEM, C. albicans cells were inoculated on sterile glass cover-slip disks in 12-well cell culture plates (CoStar, Bethesda, MD) for 12 and 24 hours at $37^{\circ} \mathrm{C}$ by dispensing a standardized cell suspension $(2 \mathrm{~mL}$ of a suspension containing $10^{6}$ cells $/ \mathrm{mL}$ in RPMI 1640) onto appropriate spherical glass disks. Meanwhile, during inoculation, Candida cells were pretreated at 6 and 18 hours with activated GNP-MB conjugate. The disks were removed after 12 and 24 hours and washed three times in sterile PBS. The resultant samples were fixed with $2 \%$ formaldehyde and $2.5 \%$ glutaraldehyde in PBS ( $\mathrm{pH} \mathrm{7.4)} \mathrm{overnight,} \mathrm{rinsed}$ three times with PBS, and dehydrated in absolute ethanol series $(70 \%$ for 10 minutes, $95 \%$ for 10 minutes, and $100 \%$ for 20 minutes). Samples were dried in desiccators prior to sputter coating with gold and observed by SEM (EVO 40; Zeiss, Jena, Germany) at $20 \mathrm{kV}$.

\section{Confocal laser scanning microscopy (CLSM)}

CLSM of Candida biofilm cells was performed as described elsewhere with slight modification. ${ }^{39}$ CLSM was used to illustrate the effect of GNP and photosensitized or activated GNP-MB conjugate on Candida cells during Candida biofilm formation. Biofilm-forming Candida cells were grown on glass cover slips by adding $4 \mathrm{~mL}$ of standardized C. albicans strain ATCC 90028 in 12-well cell culture plates (CoStar). After 12 hours, GNP, GNP-MB-treated and control Candida cells on the glass cover slips were removed, transferred to new six-well culture plates, and incubated for 45 minutes at $37^{\circ} \mathrm{C}$ in $4 \mathrm{~mL}$ of PBS containing the following fluorescent dyes as molecular probes: concanavalin A ([Con A] Alexa Fluor 488 conjugated, $25 \mu \mathrm{g} / \mathrm{mL}$; Invitrogen, Carlsbad, CA), FUN-1 (Fungolight $10 \mu \mathrm{M}$; Invitrogen) and 4,6-diamidino-2phenylindole (DAPI, $2.5 \mu \mathrm{g} / \mathrm{mL}$, Sigma-Aldrich). The excitation and emission wavelengths for FUN-1 are $543 \mathrm{~nm}$ and $560 \mathrm{~nm}$, respectively, whereas the excitation and emission wavelengths for Con A are $488 \mathrm{~nm}$ and $505 \mathrm{~nm}$, respectively. DAPI has an excitation wavelength of $358 \mathrm{~nm}$ and an emission wavelength of $461 \mathrm{~nm}$ of light. After incubation with the dyes, the disks were flipped on glass plates and the stained Candida biofilms were observed with a FluoView FV1000 (Olympus, Tokyo, Japan) confocal laser scanning microscope equipped with argon and HeNe lasers.

\section{Statistical analysis}

The effect of MB and GNP-MB conjugate on Candida biofilm formation was compared with control biofilms (without any supplement) and analyzed using Student's $t$-test. Data with $P$-values $<0.05$ were considered statistically significant.

\section{Results}

\section{Characterization of GNP}

GNPs showed a strong absorption band in the visible range due to surface plasmon resonance. Surface plasmon resonance is caused by the motion of free electrons in the conduction band caused by interaction with an electromagnetic field. ${ }^{40}$ When the frequency of the light wave became resonant with the electron motion, strong absorption was observed, which is the origin of colloidal colour. ${ }^{41,42}$ 
In the UV-visible spectrum of GNP, nanoparticles absorb light at around $534 \mathrm{~nm}$, which is a visible range of red color (Figure 1). ${ }^{43}$ Figure 2 shows a typical powder XRD pattern of GNPs and confirmed the XRD peaks 111, 200, 220 , and 311 , which are in good agreement with previously reported data. ${ }^{44,45}$ GNP size $(21 \pm 2.5 \mathrm{~nm})$ and hydrodynamic mean diameter $(22.4 \mathrm{~nm})$ were analyzed and measured by TEM and cross-correlation spectroscopy instruments, respectively (Figure 3C and D, respectively). It was observed that particles were ellipsoidal and quite stable as their sizes and shape remained constant after synthesis.

\section{Minimum fungicidal and inhibitory effect of MB and GNP-MB conjugate}

GNP showed no minimum inhibitory effect on Candida cells after serial dilution (initial concentration $0.2 \mathrm{mg} / \mathrm{mL}$ ) on microtiter plate. MB showed MIC and MFC of $62.5 \mu \mathrm{g} / \mathrm{mL}$ and $125.0 \mu \mathrm{g} / \mathrm{mL}$, respectively, whereas GNP-MB conjugate showed MIC and MFC of $31.2 \mu \mathrm{g} / \mathrm{mL}$ and $62.5 \mu \mathrm{g} / \mathrm{mL}$, respectively. GNP-MB conjugate showed twofold higher activities against $C$. albicans than $\mathrm{MB}$ alone.

\section{Physicochemical interaction of MB with GNP}

The maximum absorption spectrum of GNP measured by UV-visible spectroscopy was at $534 \mathrm{~nm}$ due to surface resonance around the GNP. MB showed a primary maximum

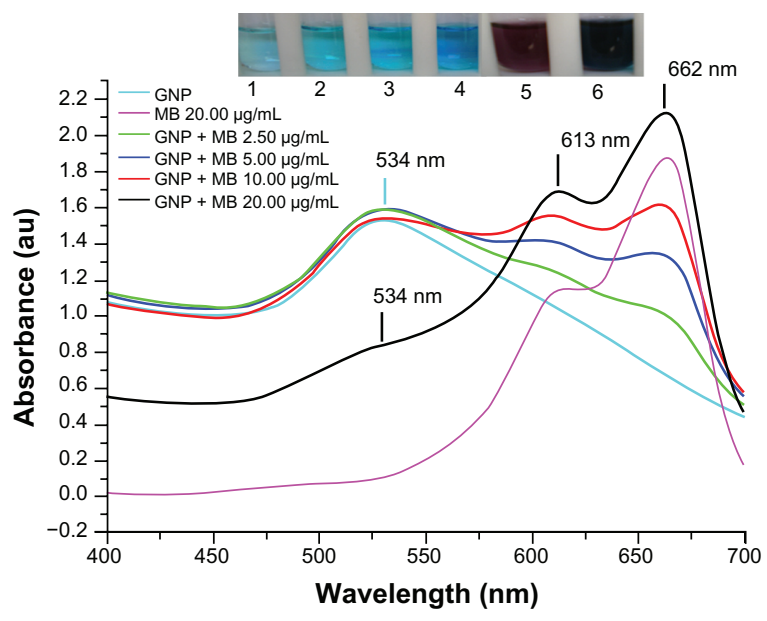

Figure I Ultraviolet-visible absorption spectra of GNP, MB, and GNP-MB conjugate. Notes: GNP has signature spectra at $534 \mathrm{~nm}$ due to surface plasmon resonance. MB shows absorption peaks at $662 \mathrm{~nm}$ and $613 \mathrm{~nm}$. With the increase of MB concentration in constant concentration of GNP $(0.2 \mathrm{mg} / \mathrm{mL})$, absorption peaks of GNP successively vanished at $534 \mathrm{~nm}$, and new enhanced absorption peaks formed at $662 \mathrm{~nm}$ and $613 \mathrm{~nm}$. Coloration pattern is shown in inset. Test tubes I, 2, 3, and 4 show MB of $2.50,5.00,10.00$ and $20.00 \mu \mathrm{g} / \mathrm{mL}$ concentrations, respectively. Test tubes 5 and 6 show GNP $(0.2 \mathrm{mg} / \mathrm{mL})$ and GNP-MB $(20.00 \mu \mathrm{g} / \mathrm{mL}$ MB), respectively. Abbreviations: GNP, gold nanoparticle; $M B$, methylene blue.

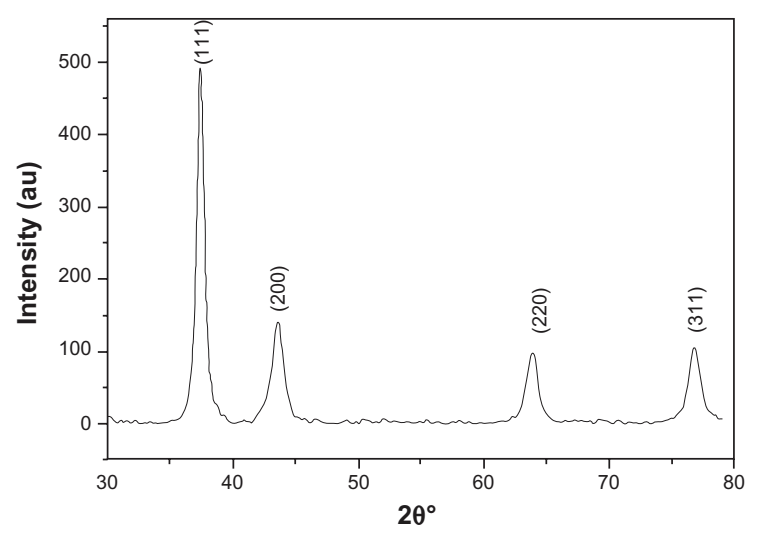

Figure 2 X-ray powder diffraction pattern by $\mathrm{Cu} K_{\alpha}$ radiation $(\lambda=1.54060 \AA)$ in $2 \theta$ ranging from $30^{\circ}$ to $80^{\circ}$.

absorption peak at $662 \mathrm{~nm}$ and secondary absorption peak at $613 \mathrm{~nm}$. After gradual addition of MB concentration up to $20 \mu \mathrm{g} / \mathrm{mL}$ in the presence of a constant concentration of GNP $(0.2 \mathrm{mg} / \mathrm{mL})$, there was a remarkable decrease in the GNP absorption peak at $534 \mathrm{~nm}$ and new peaks formed at $613 \mathrm{~nm}$ and $662 \mathrm{~nm}$ (Figure 1). The UV-visible absorption result suggests that $\mathrm{MB}$ cationic dye either absorbed on GNP or GNP aggregated after addition of MB.

Further FTIR spectroscopy, photon cross-correlation spectroscopy (particle-size analysis), and TEM were conducted to determine the absorption of MB $(20 \mu \mathrm{g} / \mathrm{mL})$ on GNP and aggregation of GNPs. The FTIR spectra of GNP-MB conjugate as compared to MB shows a sharp peak near $1600 \mathrm{~cm}^{-1}$. A blunt peak of MB near $3250 \mathrm{~cm}^{-1}$ became much more intense near $3298 \mathrm{~cm}^{-1}$ in GNP-MB conjugate. Additional suppressed and broadened bands are observed near $2698 \mathrm{~cm}^{-1}$ for GNP-MB conjugate as compared to MB (Figure 4).

GNP mean diameter was measured by photon crosscorrelation spectroscopy (particle-size analyzer) and was found to be $22.4 \mathrm{~nm}$ (Figure 3D), whereas after addition of MB $(20 \mu \mathrm{g} / \mathrm{mL})$, GNP size increased to $26.5 \mathrm{~nm}$ (Figure 3E). Further, GNP-MB size analyzed by TEM was observed to be $23 \pm 2 \mathrm{~nm}$ (Figure $3 \mathrm{~A}$ and B). Comparative studies of photon cross-correlation measurement (Figure 3D and E) showed that there was no aggregation of GNPs on addition of MB.

Fluorescence spectroscopy was used to determine the enhancement or quenching of $\mathrm{MB}$ after conjugation with GNP (Figure 5). Fluorescence spectra of MB $(20 \mu \mathrm{g} / \mathrm{mL})$ showed maximum fluorescence peak at $684 \mathrm{~nm}$ on excitation at $660 \mathrm{~nm}$, as described elsewhere. ${ }^{46} \mathrm{GNP}(0.2 \mathrm{mg} / \mathrm{mL})$ has a maximum fluorescence peak of $665 \mathrm{~nm}$ on excitation at $660 \mathrm{~nm}$. A remarkable quenching in fluorescence of 


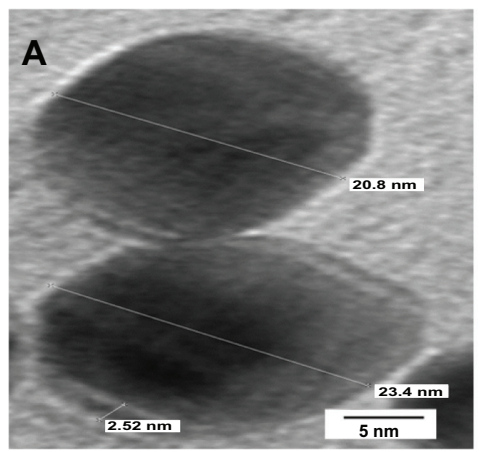

D

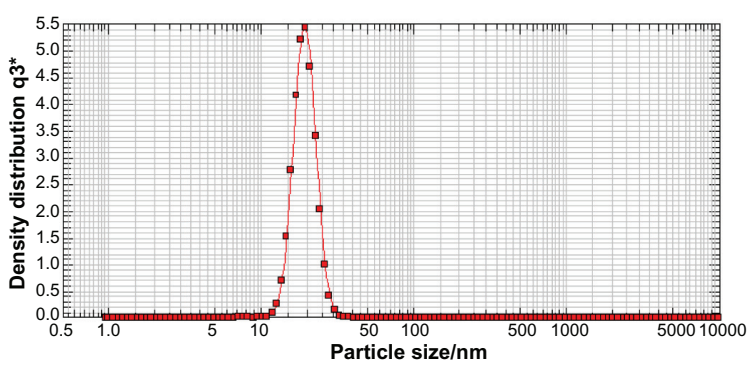

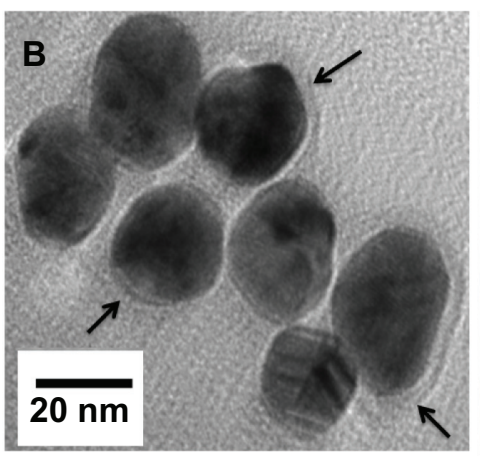

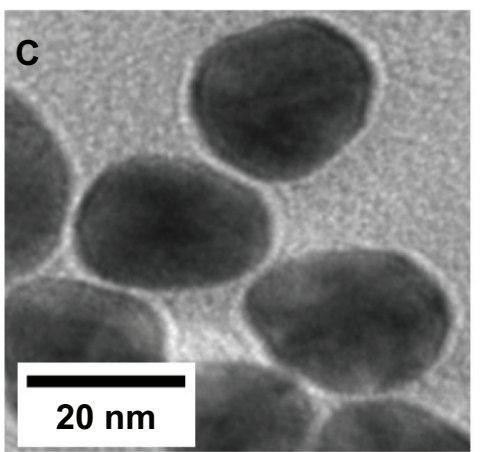

E

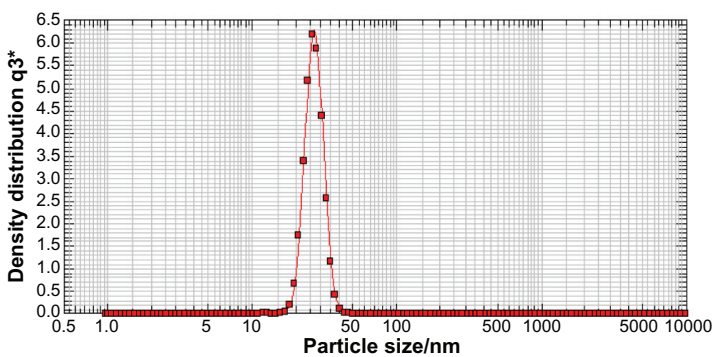

Figure 3 (A-C) Transmission electron microscopy images of GNP and GNP-MB (20 $\mu \mathrm{g} / \mathrm{mL}$; MB) conjugate. (C) Synthesized and clearly spherical colloidal GNPs with average size $21 \pm 2.5 \mathrm{~nm}$. (B) MB-conjugated GNPs and coating of MB around GNP are shown by black arrows. (A) The 2.52-nm thickness of MB coating around GNP. Photon cross-correlation spectra of GNP and GNP-MB (20 $\mu \mathrm{g} / \mathrm{mL} ; \mathrm{MB})$ conjugate are shown in (D and E) respectively. (D) Hydrodynamic mean diameter of GNP around $22.4 \mathrm{~nm}$. (E) Hydrodynamic mean diameter of GNP-MB conjugate around $26.5 \mathrm{~nm}$.

Abbreviations: GNP, gold nanoparticle; MB, methylene blue.

MB was observed on addition of GNP $(0.2 \mathrm{mg} / \mathrm{mL})$ at $684 \mathrm{~nm}$.

\section{Quantitation of Candida biofilm formation}

The antibiofilm activities of MB and GNP-MB were observed by using crystal violet and XTT biofilm reduction assays. Crystal violet assay has been used widely to measure

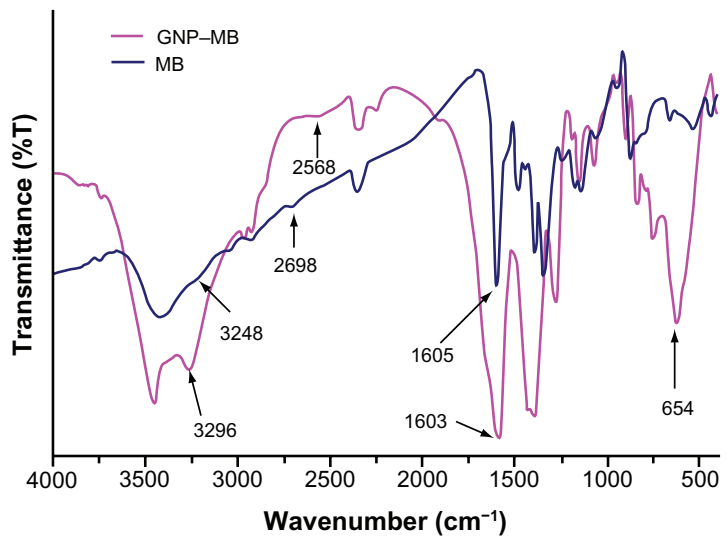

Figure 4 Percent transmittance Fourier transform infrared spectroscopy spectra of MB $(20 \mu \mathrm{g} / \mathrm{mL})$ and GNP-MB $(20 \mu \mathrm{g} / \mathrm{mL} ; \mathrm{MB})$ conjugate.

Notes: GNPs in GNP-MB conjugate show characteristic transmittance peak at $654 \mathrm{~cm}^{-1}$. GNP-MB conjugate shows the prominent peak difference as compared to $M B$, shown by black arrows.

Abbreviations: GNP, gold nanoparticle; MB, methylene blue. biofilm formation because of its amenability to large screening procedures ${ }^{47}$ Crystal violet dye was used to measure percent inhibition on biofilm formation in the presence of different compounds because it affects diffusion as well as morphological and physiological differences in individual cells that influence dye binding. ${ }^{48} \mathrm{~A}$ crystal violet assay revealed a maximum percent inhibition of Candida biofilm

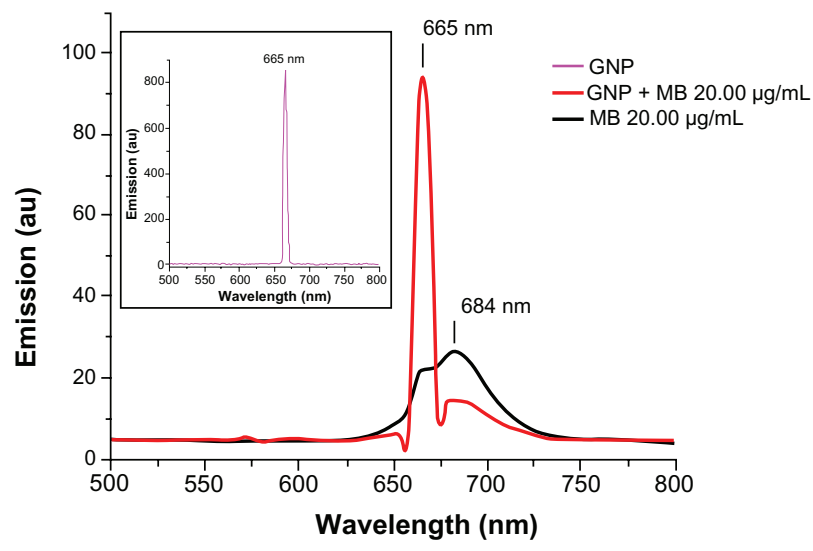

Figure 5 Fluorescence emission spectra of GNP $(0.2 \mathrm{mg} / \mathrm{mL}), M B(20 \mu \mathrm{g} / \mathrm{mL})$, and GNP-MB $(20 \mu \mathrm{g} / \mathrm{mL}$; MB) conjugate after excitation at $660 \mathrm{~nm}$.

Notes: In the presence of GNP $(0.2 \mathrm{mg} / \mathrm{mL})$, the fluorescence emission peak of $\mathrm{MB}$ quenches at $684 \mathrm{~nm}$. In inset, GNP shows a maximum fluorescent emission peak at $665 \mathrm{~nm}$.

Abbreviations: GNP, gold nanoparticle; MB, methylene blue. 
formation after 24 hours' incubation, recorded as $63.2 \%$ and $82.2 \%$ by MB $(20 \mu \mathrm{g} / \mathrm{mL})$ and GNP-MB $(20 \mu \mathrm{g} / \mathrm{mL}$; MB) conjugate, respectively (Figure 6). We used another tetrazolium salt (XTT) reduction assay for quantitative measurement of Candida biofilm formation. This assay is the most commonly used test to estimate viable biofilm growth and examine the impact of biofilm therapies. XTT assay is a more sensitive technique for the study of antifungal activity. In XTT assay, maximum percent inhibition during 24-hour treatment was found to be $81.9 \%$ and $95.4 \%$ for $\mathrm{MB}(20 \mu \mathrm{g} / \mathrm{mL})$ and GNP-MB $(20 \mu \mathrm{g} / \mathrm{mL}$; MB) conjugate, respectively (Figure 7). GNP-treated biofilms showed negligible reduction of biofilm as compared to control in both assays.

\section{CSLM and electron microscopic exploration of MB-GNP effects on Candida cells and biofilm}

SEM is important to determine the overall morphology of Candida cells and biofilm in three dimensions. Control, GNP $(0.2 \mathrm{mg} / \mathrm{mL})$, and GNP-MB $(20 \mu \mathrm{g} / \mathrm{mL}$; MB) treated biofilms were grown for 12 hours and 24 hours (Figure $8 \mathrm{~A}-\mathrm{H}$, respectively). There was no significant difference in GNP-treated (Figure 8B and F) and control biofilms (Figure $8 \mathrm{~A}$ and $\mathrm{E}$ ), shown as spherical yeast-type cells and elongated hyphae (black arrows in Figure 8A, B, $\mathrm{E}$ and $\mathrm{F}$, respectively), whereas GNP-MB-treated biofilms showed a detrimental effect, wherein Candida cells and biofilms shrank, completely ruptured (shown by black arrows

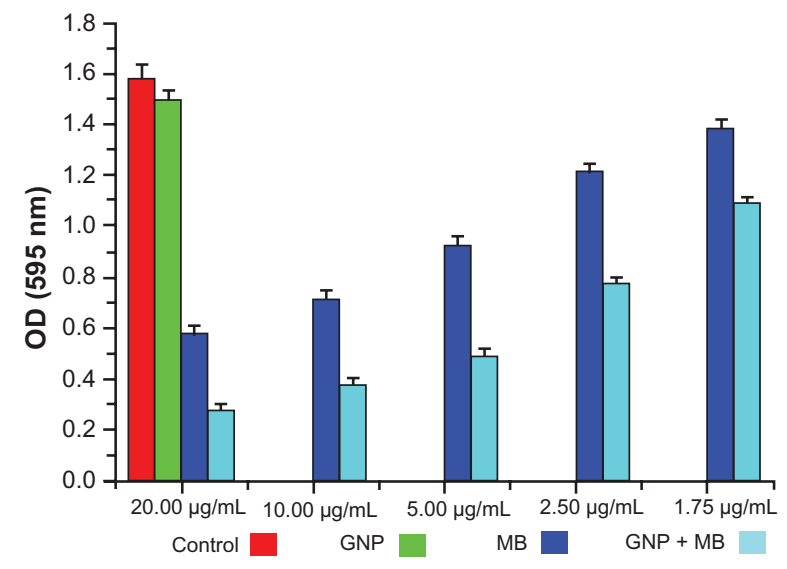

Figure 6 Crystal violet biofilm reduction assay bar plot represents the reduced biofilm optical density measurement at $595 \mathrm{~nm}$.

Notes: Here, GNP $(0.2 \mathrm{mg} / \mathrm{mL})$ optical density shows the negligible inhibition of Candida biofilm as compared to control. With the increment of $\mathrm{MB}$ concentration in GNB-MB conjugate $(1.75 \mu \mathrm{g} / \mathrm{mL}$ to $20 \mu \mathrm{g} / \mathrm{mL}$; MB), biofilm or optical density of biofilm significantly decreases in GNP-MB-treated biofilm, in comparision to MBtreated biofilm.

Abbreviations: GNP, gold nanoparticle; MB, methylene blue.

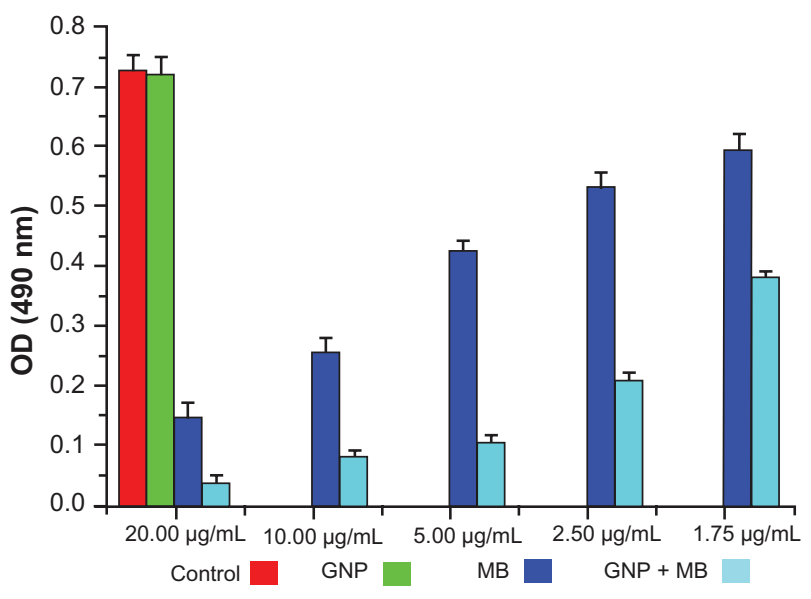

Figure 7 Bar plot represents the XTT biofilm reduction assay at $490 \mathrm{~nm}$. Notes: Here, GNP $(0.2 \mathrm{mg} / \mathrm{mL})$-treated and control biofilm show a negligible difference in optical density. With increments in MB and its concentration in GNP-MB conjugate ( $.75 \mu \mathrm{g} / \mathrm{mL}$ to $20 \mu \mathrm{g} / \mathrm{mL}$; MB), biofilm or optical density of biofilm significantly decreases in GNP-MB-treated biofilm as compared to MB-treated biofilm.

Abbreviations: GNP, gold nanoparticle; MB, methylene blue.

in Figure 8C and G), and aggregated as irregularly shaped material (shown by red arrows in Figure 8D and $\mathrm{H}$ ).

TEM was performed to further substantiate the effect of GNP-MB $(20 \mu \mathrm{g} / \mathrm{mL}$; MB) conjugate in the 12-hour-grown Candida cells. In TEM, control cell (Figure 8I) showed intact cell wall integrity and cell organelles, whereas in the presence of GNP-MB, cell wall integrity was lost (shown by black arrows in Figure 8J-L), and GNP-MB was shown in the dark-black cells (shown by red arrow in panel 8L). CLSM ultimately supported the TEM and SEM micrographs by revealing cellular metabolic activity, viability, and cell wall integrity, using FUN-1, DAPI, and Con A fluorescent dyes, respectively.

FUN-1 is transformed from a yellow to an orange-red fluorescent cylindrical or rodlike intravacuolar structure by metabolically active or viable cells, and Con-A is transformed to green fluorescence by binding to glucose and mannose residues of cell wall polysaccharides. ${ }^{49,50}$ DAPI intercalates between base pairs of DNA, specifically AT-rich regions of minor grooves, and gives blue fluorescence, which represents the polar cellular nucleus. ${ }^{51}$ GNP (0.2 mg/mL)-treated Candida cells (Figure 8N and R) have similar cytological features as compared to control cells (Figure 8M and Q). Red arrows in Figure 8Q and R, show intact vacuole in orange-red fluorescent cylindrical intravacuolar structure by FUN-1 Fluor probe. In Figure 8M, N, Q, and R, cyan arrows show the thick intact cell wall in green by cell wall-specific Fluor probe Con A. Red arrows in Figure $8 \mathrm{M}$ and $\mathrm{N}$, show the intact polar nucleus by blue DAPI fluorescent probe. After GNP-MB 

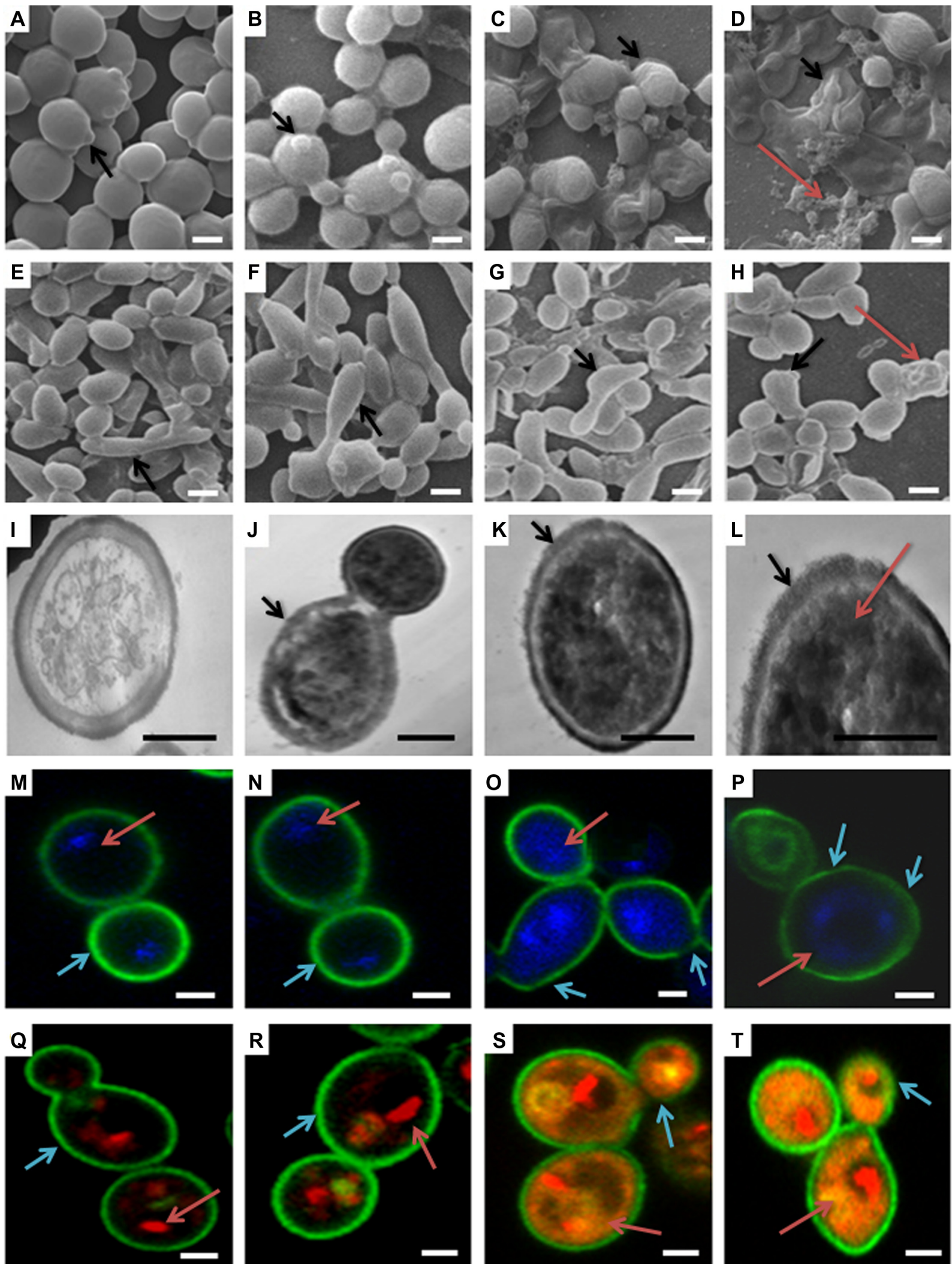

Figure 8 (A-T) Morphological, cytological, and cytometabolic effects of GNP-MB $(20 \mu \mathrm{g} / \mathrm{mL}$; MB) conjugate on Candida biofilm. Here, morphology of Candida biofilm showed by scanning electron micrographs (A-D) 12-hour-grown biofilm; (E-H) 24-hour-grown biofilm); (B and F) GNP-treated Candida biofilm; (A and E) control. (C, D, G and $\mathbf{H}$ ) Effects of GNP-MB conjugate on Candida biofilm. (J-L) Cytological effects of GNP-MB conjugate in I2-hour-grown Candida cells represented by transmission electron micrograph; (I) control; (M-T) Candida cytological perturbations in 12-hour-grown Candida cells viewed by confocal scanning micrograph; (O, P, S and T) GNP-MB treated; ( $\mathbf{N}$ and $\mathbf{R})$ GNP-treated; ( $\mathbf{M}$ and $\mathbf{Q})$ control. Bars in $(\mathbf{A}-\mathbf{T})$ are $2 \mu \mathrm{M}$ and I $\mu \mathrm{M}$, respectively.

Abbreviations: GNP, gold nanoparticle; MB, methylene blue. 
$(20 \mu \mathrm{g} / \mathrm{mL}$; MB) treatment, FUN-1 probe showed cytosolic diffused yellow and orange fluorescence, which confirmed vacuolar disintegration and fragmentation in metabolic nonviable cells (red arrows in Figure $8 \mathrm{~S}$ and $\mathrm{T}$ ) and loss of cell wall integrity by fading and thinning of Con-A green Fluor, represented by cyan arrows in Figure 8O, P, S, and T. Conjugate-treated cells showed nuclear fragmentation by sprinkled and scattered DAPI blue Fluor in cytosol (red arrows in Figure $8 \mathrm{O}$ and $\mathrm{P}$ ).

\section{Discussion}

C. albicans is one of the foremost causes of nosocomial infection, which adheres and forms a matrix-like structure around the surface of prosthetic devices and implants such as joint replacements, heart valves, and intravascular or urinary catheters. ${ }^{8}$ This matrix-like structure or biofilm shows a distinct phenotypic and chemical composition, which is not vulnerable to antimicrobial agents as compared to planktonic cells. ${ }^{10}$ It became imperative to remove these biofilm-attached implants and devices, otherwise they may disseminate candidiasis infection. ${ }^{52}$

Besides the multifactorial phenomenon, ${ }^{11-15}$ the unique properties of Candida biofilm matrix materials thwart antimicrobial activity against well-ensconced Candida cells as compared to planktonic cells. The chemical composition of ECM of Candida biofilm has not been not fully elucidated. Recently, it has been shown that a structure component of matrix and cell wall called $\beta$-1,3-glucans binds to antifungal drugs (fluconazole and amphotericin B) and minimizes antifungal activity against $C$ andida cells. ${ }^{16}$ Another putative factor that may attribute resistance to biofilms is negatively charged chemical composition in EPS, restricting the penetration of positively charged drug molecules. ${ }^{17}$

In the last two decades, nanobiotechnologists have gained more interest in inorganic nanoparticles, mostly metallic nanoparticles that are now used for bioconjugation and biological imaging in drug delivery and diagnostic applications. ${ }^{53,54}$ Metallic nanoparticles have a large surface area, and this helps the interaction of a broad gamut of drug molecules. $^{55}$

Nobel metallic nanoparticles such as colloidal GNPs are attracting significant interest as carriers of various payloads towards the target. These payloads are antitumor agents and other drugs. ${ }^{26,56}$ GNPs have some unique chemical and physical properties that make them efficient carriers and enhancers. GNP has remarkable surface plasmon resonance for imaging and fluorescence enhancing or quenching of attached drugs or dyes. ${ }^{57,58}$
We performed the most efficient and straightforward synthesis of GNPs by using a modified Turkevich-Frens method, ${ }^{32,33}$ producing colloidal GNPs of around $20 \mathrm{~nm}$. These synthesized GNPs were characterized by maximumabsorption spectra using UV-visible spectroscopy (Figure 1). XRD of synthesized GNP confirmed that the GNPs were in good agreement with previously reported data (Figure 2). ${ }^{44,45}$ Photon cross-correlation spectroscopy (particle-size analyser) (Figure 3D) and TEM findings (Figure 3C) bolstered GNP size (22.4 and $21 \pm 2.5 \mathrm{~nm}$, respectively). Here, we used appropriate and optimum size and concentration $(21 \pm 2.5 \mathrm{~nm}$ and $0.2 \mathrm{mg} / \mathrm{mL}$ ) of GNP, which is compatible with mammalian cells, as described elsewhere. ${ }^{59,60} \mathrm{GNP}(0.2 \mathrm{mg} / \mathrm{mL})$ did not show any antibiofilm (Figures 6 and 7; crystal violet and XTT biofilm reduction assay) and fungicidal (MIC) activity against Candida biofilm and Candida cells. It was earlier described that GNPs do not affect bacterial growth, but when coupled with vancomycin they show antibacterial activity. ${ }^{28}$

These charged stabilized nanoparticles have been attached or bioconjugated with a variety of photosensitizers and antibiotics. ${ }^{61,30}$ Earlier studies have been performed against pathogenic microbes by amalgamating the properties of both colloidal GNP and thiazine dyes such as $\mathrm{MB}$ and $\mathrm{TBO}$ as a GNP-thiazine conjugate. In one of the studies, GNP conjugated with TBO showed effective PDT against Staphylococcus aureus and enhanced the bactericidal effect up to $90 \%-99 \%{ }^{31}$ Recently, in another study, GNP-conjugated biodegradable and biocompatible poly(lactic-co-glycolic acid) PGLA with MB embedded showed effective antimicrobial PDT against Enterococcus faecalis-infected tooth root canal. ${ }^{62}$

Many studies have demonstrated MB-mediated PDT against bacterial and fungal infections. ${ }^{63,64}$ It was described that MB $(0.05 \mathrm{mg} / \mathrm{mL})$ inhibits $80 \%-90 \%$ of Candida cells upon treatment of 683-nm diode laser light irradiation with a $28 \mathrm{~J} / \mathrm{cm}^{2}$ energy dose. ${ }^{18}$ In another study, $0.05 \mathrm{mg} / \mathrm{mL} \mathrm{MB}$ increased membrane permeability and reduced Candida growth with irradiation of 684-nm light diode laser with $28 \mathrm{~J} / \mathrm{cm}^{2}$ energy dose. ${ }^{65}$ In our study, diode laser of $660-\mathrm{nm}$ light with $38.2 \mathrm{~J} / \mathrm{cm}^{2}$ energy dose in the presence of $\mathrm{MB}$ inhibited the Candida cells' growth (MIC; $62.5 \mu \mathrm{g} / \mathrm{mL}$ ) and showed $125.0 \mu \mathrm{g} / \mathrm{mL}$ fungicidal activity. This result is comparable with previously described results, but there is some inconsistency in previously described PDT protocols because of varying factors that influence the results of PDT. These factors are media in which particular strains are grown, type of strain, time of exposure, concentration of photosensitizer, and energy dose of laser. ${ }^{66}$ 
Most studies of GNP-conjugated photosensitizer have been performed on planktonic or suspended microbes, but these types of conjugate were never applied against microbial biofilm. This is the first study to characterize GNP-MB conjugation for examining antibiofilm activity against Candida biofilm. In the present study, we used a subconcentration of MB photosensitizer $(20 \mu \mathrm{g} / \mathrm{mL})$ and 660 -nm diode laser with $38.2 \mathrm{~J} / \mathrm{cm}^{2}$ energy against Candida biofilm, which has been reported as nonlethal against mammalian host cells. ${ }^{67}$

The spectroscopic techniques and TEM were used to determine the type of interaction between MB and GNP. In UV-absorption spectroscopy, with incremental MB concentration the plasmon resonance peak of constant concentration of GNP $(0.2 \mathrm{mg} / \mathrm{mL})$ decreases and new absorption peaks appear. The absorption peak of GNP-MB $(20 \mu \mathrm{g} / \mathrm{mL}$; MB) was significantly higher as compared with MB $(20 \mu \mathrm{g} / \mathrm{mL})$ alone (Figure 1). This new absorption peak may be attributed to aggregation of GNPs or interaction between GNP and MB. Further, three types of studies were performed to elucidate the UV-absorption finding. In the first study, FTIR spectroscopy of GNP-MB $(20 \mu \mathrm{g} / \mathrm{mL}$; MB) shows the percent transmission peaks near $1600 \mathrm{~cm}^{-1}$ and $3200 \mathrm{~cm}^{-1}$, indicating the presence of aromatic rings and primary amine $(\mathrm{N}-\mathrm{H})$, respectively, as compared to FTIR peaks of MB $(20 \mu \mathrm{g} / \mathrm{mL}){ }^{68,69} \mathrm{In}$ addition, the absence of an S-H vibration band of MB (near $2698 \mathrm{~cm}^{-1}$ ) in GNP-MB conjugate indicates deprotonation and coordination with GNP (Figure 4). ${ }^{70}$ In a second study, hydrodynamic mean diameter of GNP and conjugate was measured by photon correlation spectroscopy where GNP-MB $(20 \mu \mathrm{g} / \mathrm{mL}$; $\mathrm{MB}$ ) conjugate had a mean diameter of $26.5 \mathrm{~nm}$ as compared to colloidal GNP $(22.4 \mathrm{~nm})$. This minimal average size difference $(\sim 4 \mathrm{~nm})$ confirmed that there was no aggregation of GNP in the presence of maximum absorbance at $20-\mu \mathrm{g} / \mathrm{mL}$ concentration of $\mathrm{MB}$ (Figure 3D and E). In the third study, TEM images showed that synthesized colloidal GNPs are of an ellipsoid shape, with $21 \pm 2.5$-nm average size (Figure $3 \mathrm{C})$, and in the presence of $\mathrm{MB}(20 \mu \mathrm{g} / \mathrm{mL})$ a layer of $2 \pm 0.5 \mathrm{~nm}$ was formed around GNP (Figure $3 \mathrm{~A}$ and $\mathrm{B}$ ). TEM image (Figure $3 \mathrm{~B}$ ) shows there is no aggregation of GNP-MB conjugate at MB $(20 \mu \mathrm{g} / \mathrm{mL})$ experimental concentration. These three studies evidently substantiate GNP-MB interaction. Furthermore, FTIR and absorption studies propound the aurophilic coordination bond to GNP through sulphur atoms of $\mathrm{MB}$ and electrostatic interaction between GNP and MB, respectively.

Preliminary in vitro antimicrobial studies of GNP, $\mathrm{MB}$, and GNP-MB conjugate were carried out with MIC and MFC assay, wherein MIC and MFC of GNP-MB conjugate were found to be $31.2 \mu \mathrm{g} / \mathrm{mL}$ and $62.5 \mu \mathrm{g} / \mathrm{mL}$, respectively, as compared to MIC and MFC of MB at $62.5 \mu \mathrm{g} / \mathrm{mL}$ and $125.0 \mu \mathrm{g} / \mathrm{mL}$, respectively. GNP did not demonstrate any antifungal activity at initial constant experimental concentration $(0.2 \mathrm{mg} / \mathrm{mL})$. Inhibitory and fungicidal studies were instigated to investigate antifungal activity against Candida biofilm, wherein XTT biofilm reduction (Figure 7) and crystal violet reduction assay (Figure 6) demonstrated $95.4 \%$ and $82.2 \%$ reduction of Candida biofilm by GNP-MB conjugate, respectively, as compared to $\mathrm{MB}$, which reduced the biofilm by $81.9 \%$ and $63.2 \%$, respectively.

Three-dimensional morphological studies by SEM clearly illustrate the GNP-MB-treated Candida cells in 12- and 24-hour-grown biofilm, which are deformed, shrunken, completely ruptured, and aggregated in the form of irregularly shaped materials (Figure 8C, D, G and H).

Further, TEM and CLSM capture the cytological and cytometabolical alteration in Candida cells after GNP-MB conjugate treatment. Our TEM micrograph shows that the treated cells lost their cell wall integrity and increased GNP-MB conjugate permeability; as a consequence, GNP-MB conjugate penetrated the Candida cells and thus caused cytological perturbation (Figure 8J-L). FUN-1, Con-A, and DAPI fluorescent probes in CLSM micrographs illustrate the decrease of metabolic viability (Figure $8 \mathrm{O}$ and $\mathrm{P}$ ), loss of cell wall integration (Figure 8O, P, S, and T), and fragmentation of nucleus or degradation of nuclear DNA (Figure 8S and T), respectively.

Our fluorescence spectroscopic study investigated type of reactive species or molecules produced by GNP-MB conjugate in PDT that are responsible for morphological as well as cytological perturbation of Candida cells. On 660-nm excitation, GNP $(0.2 \mathrm{mg} / \mathrm{mL})$ quenched the weak fluorescence of MB at $684 \mathrm{~nm}$ (Figure 5) and acted as a quencher. It was previously reported that GNP acts as a quencher as well as enhancer of fluorophores, and these two opposite effects are due to various factors, as described elsewhere. ${ }^{71}$ Primarily, GNP-mediated quenching of fluorophore is caused by two phenomena, nonradiative energy transfer from fluorophore to GNP and collision dynamics between GNP and fluorophore, as described earlier. ${ }^{72,73}$ In conjugate, MB relaxes to ground state by nonradiative energy decay and forms free radical species such as hydroxyls and superoxides, as described previously. ${ }^{31}$ Consequently, this free hydroxyl radical production addresses the type I phototoxicity, as described earlier. ${ }^{21}$ 


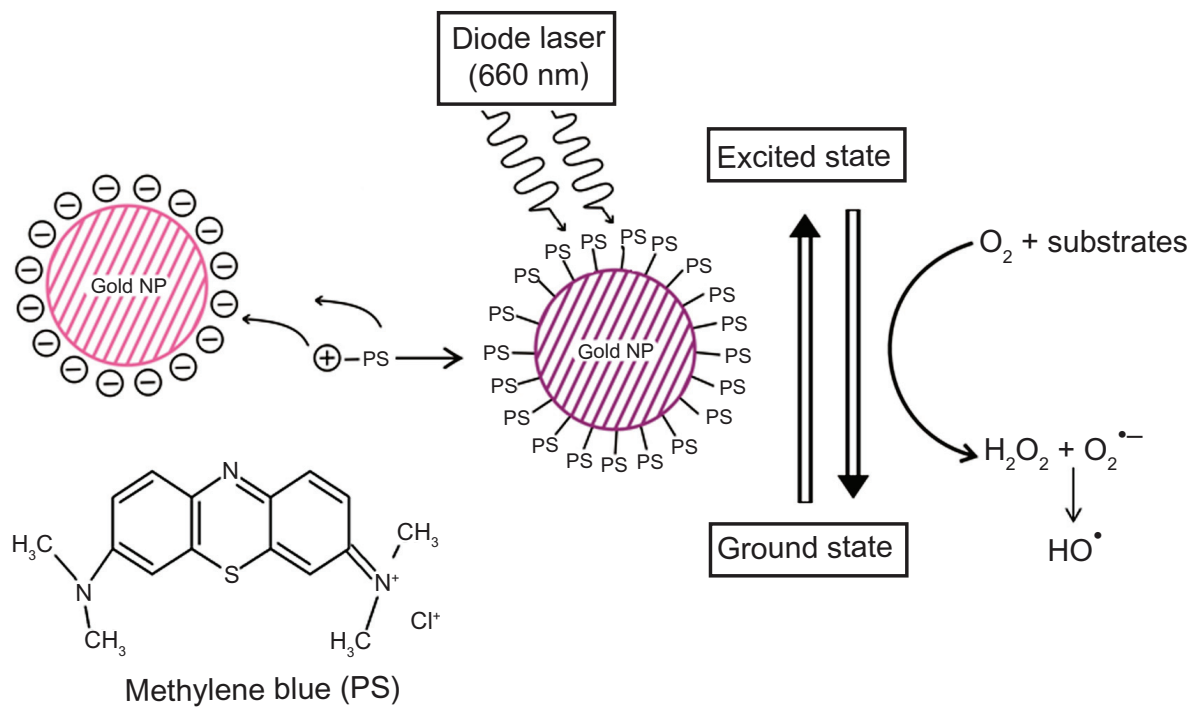

Figure 9 Schematic overview of conjugation of photosensitizer MB with GNP.

Notes: Specific $660-\mathrm{nm}$ wavelength of diode laser transits MB of GNP-MB conjugate to an excited state. Nonradiative energy decay by GNP of MB causes the transition to ground state, which results in the formation of hydroxyl free radicals in the presence of molecular oxygen and substrates around the vicinity of the conjugate (type I phototoxicity). Abbreviations: GNP, gold nanoparticle; MB, methylene blue.

\section{Conclusion}

This study investigated antimicrobial and antibiofilm activity of GNP-MB conjugate against Candida biofilm. SEM, TEM, and CLSM micrographs show the detrimental effects of conjugate, such as perturbation of Candida biofilm, cell wall integrity, nuclear disintegration, and metabolic viability. Quenching of fluorescence of MB in GNP-MB conjugate confirms type I phototoxicity against Candida biofilm by producing hydroxyl free radicals, as shown in the proposed model (Figure 9). This is the first time we have developed an alternative, efficient, and novel GNP-MB-mediated Candida antibiofilm PDT approach. Microbial biofilm is one of the most important factors in the worldwide increase of multiple drug-resistant pathogens. Moreover, Candida biofilm on medical implants and prosthetic devices necessitates immediate replacement and thus increased treatment cost. Therefore, this novel approach may be a good alternative to control infection in hospital and clinical settings.

\section{Acknowledgments}

The authors would like to acknowledge Drs Gajender Saini and Ruchita Pal, Advanced Instrumentation Research Facility, JNU, for providing TEM and SEM instrumental support. The authors would also like to acknowledge DBT, government of India, for the support and internal facilities of the department. This work was supported by internal funds of Biotechnology Unit, AMU and DBT grant, BT/PR11453/ BID/07/296/2009 to AUK.

\section{Disclosure}

The authors report no conflicts of interest in this work

\section{References}

1. Donlan RM. Biofilms: microbial life on surfaces. Emerg Infect Dis. 2002;8:881-890.

2. CostertonJW,LewandowskiZ, CaldwellDE, KorberDR,Lappin-ScottHM Microbial biofilms. Annu Rev Microbiol. 1995;49:711-745

3. Douglas LJ. Medical importance of biofilms in Candida infections. Rev Iberoam Micol. 2002;19:139-143.

4. Douglas LJ. Candida biofilms and their role in infection. Trends Microbiol. 2003;11:30-36.

5. MacCallum D. Candida albicans: New Insights in Infection, Disease and Treatement. In: Kavanagh K, editor. New Insights in Medical Mycology. Dordrecht: Springer; 2007.

6. Pfaller MA, Diekema DJ. Epidemiology of invasive candidiasis: a persistent public health problem. Clin Microbiol Rev. 2007;20:133-163.

7. Fidel PL Jr. Candida-host interactions in HIV disease: relationships in oropharyngeal candidiasis. Adv Dent Res. 2006;19:80-84.

8. Kojic EM, Darouiche RO. Candida infections of medical devices. Clin Microbiol Rev. 2004;17:255-267.

9. Edmond MB, Wallace SE, McClish DK, Pfaller MA, Jones RN, Wenzel RP. Nosocomial bloodstream infections in United States hospitals: a three-year analysis. Clin Infect Dis. 1999;29:239-244.

10. Aslam S. Effect of antibacterials on biofilms. Am J Infect Control. 2008;36:S175

11. Baillie GS, Douglas LJ. Matrix polymers of Candida biofilms and their possible role in biofilm resistance to antifungal agents. J Antimicrob Chemother. 2000;46:397-403.

12. Baillie GS, Douglas LJ. Effect of growth rate on resistance of Candida albicans biofilms to antifungal agents. Antimicrob Agents Chemother 1998;42:1900-1905.

13. LaFleur MD, Kumamoto CA, Lewis K. Candida albicans biofilms produce antifungal-tolerant persister cells. Antimicrob Agents Chemother 2006;50:3839-3846

14. Ramage G, Bachmann S, Patterson TF, Wickes BL, Lopez-Ribot JL. Investigation of multidrug efflux pumps in relation to fluconazole resistance in Candida albicans biofilms. J Antimicrob Chemother 2002;49:973-980 
15. Kuhn DM, Ghannoum MA. Candida biofilms: antifungal resistance and emerging therapeutic options. Curr Opin Investig Drugs. 2004;5: 186-197.

16. Vediyappan G, Rossignol T, d'Enfert C. Interaction of Candida albicans biofilms with antifungals: transcriptional response and binding of antifungals to beta-glucans. Antimicrob Agents Chemother. 2010;54:2096-2111.

17. Hugo WB, Russell AD. Hugo and Russell's Pharmaceutical Microbiology, 7th ed. Malden: Blackwell Science; 2004.

18. Munin E, Giroldo LM, Alves LP, Costa MS. Study of germ tube formation by Candida albicans after photodynamic antimicrobial chemotherapy (PACT). J Photochem Photobiol B. 2007;88: 16-20.

19. Peloi LS, Soares RR, Biondo CE, Souza VR, Hioka N, Kimura E. Photodynamic effect of light-emitting diode light on cell growth inhibition induced by methylene blue. J Biosci. 2008;33:231-237.

20. MacDonald I, Dougherty TJ. Basic principles of photodynamic therapy. J Porphyr Phthalocyanines. 2001;5:105-129.

21. Castano AP, Demidova TN, Hamblin MR. Mechanisms in photodynamic therapy: part one - photosensitizers, photochemistry and cellular localization. Photodiagnosis Photodyn Ther. 2004;1:279-293.

22. Wood S, Nattress B, Kirkham J, et al. An in vitro study of the use of photodynamic therapy for the treatment of natural oral plaque biofilms formed in vivo. J Photochem Photobiol B. 1999;50:1-7.

23. Soukos NS, Socransky SS, Mulholland SE, Lee S, Doukas AG. Photomechanical drug delivery into bacterial biofilms. Pharm Res. 2000;17:405-409.

24. Bhatti M, MacRobert A, Meghji S, Henderson B, Wilson M. A study of the uptake of toluidine blue $\mathrm{O}$ by Porphyromonas gingivalis and the mechanism of lethal photosensitization. J Photochem Photobiol. 1998;68:370-376.

25. Hu M, Chen J, Li ZY, et al. Gold nanostructures: engineering their plasmonic properties for biomedical applications. Chem Soc Rev. 2006;35: 1084-1094.

26. Han G, Ghosh P, Rotello VM. Functionalized gold nanoparticles for drug delivery. Nanomedicine. 2007;2:113-123.

27. Pissuwan D, Valenzuela SM, Miller CM, Cortie MB. A golden bullet? Selective targeting of Toxoplasma gondii tachyzoites using antibodyfunctionalized gold nanorods. Nano Lett. 2007;7:3808-3812.

28. Huang WC, Tsai PJ, Chen YC. Functional gold nanoparticles as photothermal agents for selective-killing of pathogenic bacteria. Nanomedicine (Lond). 2007;2:777-787.

29. Williams DN, Ehrman SH, Holoman TRP. Evaluation of the microbial growth response to inorganic nanoparticles. J Nanobiotechnology. 2006;4:3.

30. Narband N, Uppal M, Dunnill CW, Hyett G, Wilson M, Parkin IP. The interaction between gold nanoparticles and cationic and anionic dyes: enhanced UV-visible absorption. Phys Chem Chem Phys. 2009;11: 10513-10518.

31. Narband N, Tubby S, Parkin IP, et al. Gold nanoparticles enhance the toluidine blue-induced lethal photosensitisation of Staphylococcus aureus. Curr Nanosci. 2008;4:409-414.

32. Turkevich J, Stevenson PC, Hillier J. A study of the nucleation and growth processes in the synthesis of colloidal gold. Discuss Faraday Soc. 1951;11:55-75.

33. Frens $\mathrm{G}$. Controlled nucleation for the regulation of the particle size in monodisperse gold suspensions. Nature. 1973;241:20-22.

34. Tobudic S, Kratzer C, Lassnigg A, Graninger W, Prester E. In vitro activity of antifungal combinations against Candida albicans biofilms. J Antimicrob Chemother. 2010;65:271-274.

35. Djordjevic D, Wiedmann M, McLandsborough LA. Microtiter plate assay for assessment of Listeria monocytogenes biofilm formation. Appl Environ Microbiol. 2002;68:2950-2958.

36. Jin Y, Zhang T, Samaranayake YH, Fang HHP, Yip HK, Samaranayake LP. The use of new probes and stains for improved assessment of cell viability and extracellular polymeric substances in Candida albicans biofilms. Mycopathologia. 2005;159:353-360.
37. Osumi M. The ultrastructure of yeast: cell wall structure and formation. Micron. 1998;29:207-233.

38. Hawser SP, Douglas LJ. Biofilm formation by Candida species on the surface of catheter materials in vitro. Infect Immun. 1994;62:915-921.

39. Chandra J, Kuhn DM, Mukherjee PK, Hoyer LL, Ghannoum MA. Biofilm formation by the pathogen $C$. albicans: development, architecture, and drug resistance. J Bacteriol. 2001;183:5385-5394.

40. Link S, El-Sayed MA. Shape and size dependence of radiative, nonradiative and photothermal properties of gold nanocrystals. Int Rev Phys Chem. 2000;19:409-453.

41. Noginov MA, Zhu G, Bahoura M, et al. The effect of gain and absorption on surface plasmons in metal nanoparticles. Appl Phys B. 2006;86: 455-460.

42. Amendola V, Meneghetti M. Size evaluation of gold nanoparticles by UV-vis spectroscopy. J Phys Chem C. 2009;113:4277-4285.

43. Dong S, Tang C, Zhou H, Zhao H. Photochemical synthesis of gold nanoparticles by the sunlight radiation using a seeding approach. Gold Bull. 2004;37:3-4.

44. Luo Y. Formation of submicrometer-scale gold nanoparticle aggregates and their self-organization into "supracrystals." Colloid J. 2007;69: 391-393.

45. Hu J, Wang Z, Li J. Gold nanoparticles with special shapes: controlled synthesis, surface-enhanced Raman scattering, and the application in biodetection. Sensors. 2007;7:3299-3311.

46. Lee SK, Mills A. Novel photochemistry of leuco-methylene blue. Chem Commun. 2003;18:2366-2367.

47. Pitts B, Hamilton MA, Zelver N, Stewart PS. A microtiterplate screening method for biofilm disinfection and removal. J Microbiol Methods. 2003;54:269-276.

48. Niu C, Gilbert ES. Colorimetric method for identifying plant essential oil components that affect biofilm formation and structure. Appl Environ Microbiol. 2004;70:6951-6956.

49. Millard PJ, Roth BL, Yue ST, Haugland RP. Development of the FUN-1 family of fluorescent probes for vacuole labeling and viability testing of yeasts. Appl Environ Microbiol. 1997;63:2897-2905.

50. Mandal DK, Brewer CF. Differences in the binding affinities of dimeric concanavalin A (including acetyl and succinyl derivatives) and tetrameric concanavalin A with large oligomannose-type glycopeptides. Biochemistry. 1993;18:5116-5120.

51. DarzynkiewiczZ, Traganos F, Kapuscinski J, Staiano-Coico, Melamed MR. Accessibility of DNA in situ to various fluorochromes: relationship to chromatin changes during erythroid differentiation of Friend leukemia cells. Cytometry. 1984;5:355-363.

52. Donlan RM, Costerton JW. Biofilms: survival mechanisms of clinically relevant microorganisms. Clin Microbiol Rev. 2002;15:167-193.

53. Daniel MC, Astruc D. Gold nanoparticles: assembly, aupramolecular chemistry, quantum-size-related properties, and applications toward biology, catalysis, and nanotechnology. Chem Rev. 2004;104:293-346.

54. Parak WJ, Gerion D, Pellegrino T, et al. Biological applications of colloidal nanocrystals. Nanotechnology. 2003;14:R15-R27.

55. Holister P, Weener JW, Romas Vas C, Harper T. Nanoparticles: Technology White Papers 3. Ilkley: Cientific; 2003.

56. Li J, Wang X, Wang C, et al. The enhancement effect of gold nanoparticles in drug delivery and as biomarkers of drug-resistant cancer cells. Chem Med Chem. 2007;2:374-378.

57. Tam F, Goodrich GP, Johnson BR, Halas NJ. Plasmonic enhancement of molecular fluorescence. Nano Lett. 2007;7:496-501.

58. Glomm WR. Functionalized gold nanoparticles for applications in bionanotechnology. J Dispers Sci Technol. 2005;26:389-414.

59. Connor EE, Mwamuka J, Gole A, Murphy CJ, Wyatt MD. Gold nanoparticles are taken up by human cells but do not cause acute cytotoxicity. Small. 2005;1:325-327.

60. Pernodet N, Fang X, Sun Y, et al. Adverse effects of citrate/gold nanoparticles on human dermal fibroblasts. Small. 2006;6:766-773.

61. Burygin GL, Khlebtsov BN, Shantrokha AN, Dykman LA, Bogatyrev VA, Khlebtsov NG. On the enhanced antibacterial activity of antibiotics mixed with gold nanoparticles. Nanoscale Res Lett. 2009;4:794-801. 
62. Pagonis TC, Chen J, Fontana CR, et al. Nanoparticle-based endodontic antimicrobial photodynamic therapy. J Endod. 2010;36:322-328.

63. Usacheva MN, Teichert MC, Biel MA. Comparison of the methylene blue and toluidine blue photobactericidal efficacy against gram-positive and gram-negative microorganisms. Lasers Surg Med. 2001;29: 165-173.

64. de Souza SC, Junqueira JC, Balducci I, Koga-Ito CY, Munin E, Jorge AOC. Photosensitization of different Candida species by low power laser light. J Photochem Photobiol B. 2006;83:34-38.

65. Giroldo LM, Felipe MP, de Oliveira MA, Munin E, Alves LP, Costa MS Photodynamic antimicrobial chemotherapy (PACT) with methylene blue increases membrane permeability in Candida albicans. Lasers Med Sci. 2009;24:109-112.

66. Wilson M, Mia N. Sensitization of Candida albicans to killing by lowpower laser light. J Oral Pathol. 1993;22:354-357.

67. Xu Y. Endodontic antimicrobial photodynamic therapy:safety assessment in mammalian cell cultures. J Endod. 2009;35:1567-1572.

68. Tsai SW, Liaw JW, Hsu FY, Chen YY, Lyu MJ, Yeh MH. Surface-modified gold nanoparticles with folic acid as optical probes for cellular imaging. Sensors. 2008;8:6660-6673.
69. Anderson K, Young S, Jiang H, et al. Plasma enhanced copolymerization of amino acid and synthetic monomers. Langmuir. 2012;28:1833-1845.

70. Zhang X, Wang S, Shen Q. The electrochemical behavior of $p$-aminophenol at a $\omega$-mercaptopropionic acid self-assembled gold electrode. Microchimica Acta. 2005;149:37-42.

71. Kang KA, Wang J, Jasinski JB, Achilefu S. Fluorescence manipulation by gold nanoparticles: from complete quenching to extensive enhancement. J Nanobiotechnology. 2011;9:16.

72. Dulkeith E, Morteani AC, Niedereichholz T, et al. Fluorescence quenching of dye molecules near gold nanoparticles: radiative and nonradiative effects. Phys Rev Lett. 2002;89:203002.

73. Dubertret B, Calame M, Libchaber AJ. Single-mismatch detection using gold-quenched fluorescent oligonucleotides. Nat Biotechnol. 2001;19:365-370
International Journal of Nanomedicine

\section{Publish your work in this journal}

The International Journal of Nanomedicine is an international, peerreviewed journal focusing on the application of nanotechnology in diagnostics, therapeutics, and drug delivery systems throughout the biomedical field. This journal is indexed on PubMed Central,

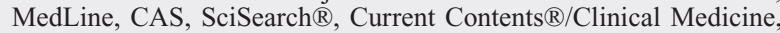

\section{Dovepress}

Journal Citation Reports/Science Edition, EMBase, Scopus and the Elsevier Bibliographic databases. The manuscript management system is completely online and includes a very quick and fair peer-review system, which is all easy to use. Visit http://www.dovepress.com/ testimonials.php to read real quotes from published authors. 